\title{
Embodied Urban Cartographies: Women's Daily Trajectories on Public Transportation in Guadalajara, Mexico
}

\author{
Azucena Gollaz Morán
}

\section{INTRODUCTION}

For many years, I had to take long trips by public transportation in Guadalajara, Mexico. I spent about three hours every day riding buses, waiting at bus stops, taking the metro and walking the streets. In those trajectories, I often witnessed and experienced gender-based violence. I perceived the spatial dichotomy between public and private spaces and observed that the urban infrastructure was mostly set up to fulfil working conditions with a focus on the productive needs to get to work, rather than reproductive work which particularly impacts women. Those experiences led me to realized that my urban experience was gendered and embodied. My body was constantly (sexually) attacked because I was a

\footnotetext{
A. Gollaz Morán $(\bowtie)$

International Institute of Social Studies, Erasmus University Rotterdam, The Hague, The Netherlands

e-mail: gollazmoran@iss.nl
} 
woman. It was also clear to me, that it was through my body that I experienced the city. I felt on my skin every unwanted touch I got on the bus. I felt the fear in my chest every time I had to walk down a dark and empty street while being followed by a man. Adding to that, I became aware of how other axes of my identity, like my social class, ethnic/racial markings and age, were part of that gendered and embodied experience. And I began to wonder: how do other women experience the urban geography, its divisions and the structural inequities? What are their embodied experiences of their daily trajectories in a public transportation system that mostly responds to productive needs?

I decided to put these reflections and questions at the centre of my Ph.D. research. My aim was to shed light on how the intersection of certain power structures and identity axes shape women's urban embodied experience and on how women transform urban spaces through their daily practices. To perform this analysis, I mapped women's daily trajectories to work by public transportation. The cartographies I made, aimed to problematize the urban experience in relation to the identity axis and power structures of gender, age, social class, ethnicity/skin colour, corporality, religion, sexual orientation and disability because those are the most important assemblages of privilege and oppression that operate both socially and spatially in Guadalajara.

I used mapping methods and reclaimed them as a feminist tool to graphically portray the intersectional geography of exclusion that operates within urban spaces and the ways it shapes women's embodied urban lives. I used feminist cartography to chart the ways in which women transform the urban every day through their daily trajectories. Feminist cartography places the subject, their embodiment and their experience at the centre of producing cartographic media; contrary to the patriarchal tradition of creating maps in a disembodied manner, claiming the neutrality of the territories (D'Ignazio \& Klein, 2020; Pirani et al., 2020). In this way feminist cartography helps to shift the ways spaces are imagined, created and recreated.

From October 2019 to March 2020, I worked with ten women who worked outside their homes from the ages of 23-50 and together navigated Guadalajara $^{l}$ (Mexico). I mapped their daily trajectories to work

\footnotetext{
${ }^{1}$ Guadalajara is the second biggest metropolis in Mexico and among the ten largest cities in Latin America (LA). It is inhabited by 5 million people (IIEG, 2017). Metropolis all over the world are part of a global dynamic in which urban spaces are highly contested
} 
by public transportation. As they travel to work these women face the multiple geographical, economic and cultural constraints that the city entails for women daily. I draw their daily geographies by mapping how their travels are differently marked by structural constraints. I took into consideration the identity axes and power structures of gender, age, social class, skin colour, corporality, ${ }^{2}$ religion, sexual orientation and disability. I used the following set of mapping methods:

- Emotional and trajectory mapping: I mapped women's geographical daily trajectories to work and the most frequent emotions they experienced in the different spaces they go through.

- Relief Maps: I mapped their experiences of comfort and discomfort related to specific identity axes and power structures in the different spaces they go through in their daily trajectories.

- Accompanied Trajectories and Walking Interviews: I accompanied the women in their trajectories from work to home and talked with them about their experiences in the different spaces they go through daily.

This chapter reflects on the methodology I created in this research process which I call "women's comprehensive embodied urban cartographies". Before explaining how I created the maps, I will discuss the relevance of mapping women's urban experience from an embodied and intersectional perspective through this focus on their daily trajectories. I then examine how I met the women in order to create the cartographies. After that, I show how these maps help us to understand the mutual constitution of gender and urban spaces. Finally, I reflect on the work's challenges and limitations.

as cities have become the centres of political decision-making and where most of the population live. Latin American cities are considered the most unequal in the world based on their high rates of spatial and social segregation and divisions. Latin America is also the most urbanized, with $80 \%$ of its population living in cities (UN-Habitat, 2012: 167).

${ }^{2}$ I use the term corporality to conceptualize women's physical complexion. The women I worked with highlight the relevance of their body shape and size in their urban experience which I theorize as a power structure and identity axis. 


\section{The Point of Departure}

In the past few years, feminist urban geographers have created gendered and intersectional understandings of urban spaces. Theorists in the field have pointed out how the city dynamics of, for instance, exclusion or oppression operate through regimes of difference, which are geographical (Bondi \& Rose, 2003). However, the incorporation of the subject in spatial theories has lacked a profound understanding of the embodiment dimension. In contrast, research in the arena of body politics has extensively researched bodies, embodiment and emotions, but has very often forgotten the spatial dimension (Lidón, 2013: 702). I decided to bring together theories of body politics together with feminist urban geography in order to understand more deeply the relationship among gender and other axes of embodiment in urban dynamics.

My starting point was that women's daily trajectories are a window to analyse women's embodied experience of the city and the ways in which they socially and spatially construct the city space. The daily experience of travelling in the city configures women's subjectivity and embodiment (Lidón, 2013). The nature and forms of women's trajectories expose diverse aspects of power relations in urban spaces. In this approach, the public space is a key element in the configuration of any city because it is subject to appropriation by different institutions and people and as such, it is both a physical and symbolic expression of the societal power relations in specific urban geographies.

Although feminist theorists have questioned and challenged the western dichotomous understanding of space and gender that divides the spheres relating the "private" to the feminine and the "public" to the masculine, there are still powerful notions that matter in the configuration of spatiality of social relations. Notions of private and public spheres operate at different scales and have distinctive implications according to the geographic, social and cultural context (Bondi, 1998). In my research, I examined the way the private-public dichotomy continues (or not) to configure the material urban geography of the dynamics shaping Guadalajara. In mapping the women's trajectories, I traced how the city is lived by women working outside the home in order to examine if the traditional connotations of public/private are breaking down. 


\section{THE INTERSECTIONAL AND EMbodied URBAN EXPERIENCE}

In this section I go further into the spatial and social public-private dichotomy operating in Guadalajara. I look at the multiple implications for the intersections of gender, social class and ethnicity/skin colour power structures, and thus for the intersectional urban experience of women.

In the case of Guadalajara, the spatial dichotomy between public and private spheres creates a labour geography dynamic based on the sexual division of work and contributes to establish binary and rigid normative gender roles. The productive zones are mainly in the central areas, while the housing sectors are mostly concentrated in the peripheries (Cuadra Urbanismo, 2016). The urban growth pattern marked by developing large neighbourhoods far away from the central zones-isolated from formal jobs, services and public transit-promotes the full-time gender role of the household caretaker, making it very hard for women to access the formal job market. To commute from the peripheries to the central areas requires time and resources, but recently, living in the peripheries was the only option for most of the population in need of a house due to the high housing prices in the central areas and the growth patterns of the metropolis (Cuadra Urbanismo, 2016). Because women in Guadalajara are still the main caregivers and dedicate more time to household activities than men, they have less time and more spatial constraints when it comes to seeking remunerated jobs. In recent years, there has been a massive incorporation of women into the paid labour force (Calonge Reillo, 2014; Ramírez Saíz \& Safa Barraza, 2009). They have taken the jobs which are more precarious, flexible and less well remunerated, under the heteronormative ideology that their earnings only complement the main household income earned by men (Calonge Reillo, 2014; Jalisco Cómo Vamos, 2018).

In the metropolis, there is another division that intersects with the gendered dynamic of centre-periphery, which is the one between the East and the West. It responds to a segregation of the population based on ethnicity and class when the city was founded by the Spanish colonizers in 1542 (De la Torre, 1998: 46). The first settlements created by the Spanish colonizers are in Guadalajara's downtown, around the central square, the cathedral and the royal and administrative buildings, on the East side. Then, on the West side, popular barrios (neighbourhoods) were 
developed, "where the indigenous and poor Guadalajara were confined: the poor class that provided to the Spanish"3 (Aceves et al., 2004: 286). The relation between the two sides of the city was also spatialized and suffered multiple transformations as the city's divide grew.

There is a disparity among the different areas regarding the quality and availability of urban infrastructure and resources that shows a relation between the two spatial divisions with women's access to the city's goods and services. The urban marginalization index by neighbourhood (IIEG, 2010) that measures access to basic educational and health services, housing quality and child mortality rates, shows that the people living in conditions of "high or very high marginalization" are spatially concentrated in the outskirts of the metropolis, especially in the East and the South (Limberopulos Fernández \& Cervantes García Rulfo, 2017). Consequently, women who live in the peripheries and in the East, not only have more spatial constraints to have remunerated jobs, but also have less access to health, education and public services.

In this context, a woman who decides to take a remunerated job outside the household must navigate these urban-gendered dynamics. In their trajectories to work, they deal with an oppressive-gendered labour geography as well as gendered spatial urban divisions. Women who use public transportation to go to work must face a gendered transit system, which is principally designed to meet men's needs. It assumes linear trips at peak hours: from home to work and vice versa. Research points out that women have multi-layered and complex travel trajectories because women's purposes for using public transportation are usually a combination of productive and reproductive work (Godinez et al., 2020). Due to unequal care work distribution, in one day, a woman may need to go to her place of work, but only after taking her children to school. Then, on her way back home, she first may need to buy groceries and pick the children up. So, they often make different stops within one trip or make various trips.

Very often, women travel accompanied by children or other people for whom they care. Public transit vehicles are usually crowded, making it very hard to travel accompanied by children or people facing mobility challenges (the elderly, people with disabilities, etc.). Also, they tend to

${ }^{3}$ Translated by author. 
carry bags to transport groceries, children's backpacks, etc. The transportation system is not designed for these kinds of needs (Godinez et al., 2020). There is no space to accommodate grocery bags or baby strollers. Additionally, women usually travel at non-peak hours, when there is less frequency of transportation. As a result, their journey is more time consuming as well as more expensive. The transit system charges per trip, so one journey with several stops costs more. They also pay for the people with whom they travel. Many times, the routes don't accommodate their needs, so they pay for taxis or they walk. They choose these options also when they feel their safety on the transport system is threatened (Godinez et al., 2020).

In a metropolis that is car-oriented, the use of public transportation is segmented by social class. The public transportation system is deficient, dangerous and expensive. It is a marker of social class and a cultural aspiration to own a car. There is a substantial income difference between women who use public transportation and women who use private transportation as their main form of transport. The $58.8 \%$ of women who use public transit have an income of 5 thousand pesos monthly. The same percentage of women who use private transportation has an income of 5-10 thousand (Godinez et al., 2020: 57).

In addition, the violence and fear of the public space are among the main markers of women's urban experience. The fear of the public space becomes central when understanding women's daily trajectories because it influences women's possibilities to appropriate and transform urban spaces. Gender-based violence and sexual violence in public spaces is one of the main problems for women in Latin American cities. In Guadalajara, eight out of ten women have been sexually harassed in public transport at least once in their lives (El Informador, 2014: NP; Jalisco Cómo Vamos, 2018: 50). In addition, women's identities intersect with other power structures operating in the city such age, religion, sexual preference, corporality and physical abilities. These different structures inform the exercise of power and the constitution of gendered identities and spaces (Rodó-de-Zárate \& Baylina, 2018).

\section{Comprehensive Embodied Urban Cartographies}

In this section I look at the embodied cartographies of women's daily trajectories to work by public transportation in order to understand how power structures shape women's urban experience and the ways women 
transform urban spaces. From October 2019 to February 2020, I navigated Guadalajara metropolis with ten working women living in the peripheries and the East Side of the metropolis. I worked with them to elaborate comprehensive cartographies of their embodied urban experience and (re-)making strategies of the urban. The process of contacting the women was through my network. I asked friends and contacts if they knew women who made long commutes to their workplace across the city. Through them I met different women who brought me in contact with other women. I began my research by engaging with ten women who make the journey "centre-periphery" and "the East-West" and use public transportation as their main form of transport. They differ in relation to age, religion, sexual orientation, social class, skin colour, corporality and physical abilities. I asked each of the women to identify themselves in relation to these identity axes and power structures. These intersectional differences are expressed in their embodied experiences of their urban lives.

My relationship with the women was built from encounter to encounter. I was acutely aware of the question of how to build trust and to avoid being oppressive and extractive to the women's lives while still meeting my research objectives. I kept a journal in order to reflect on the many ways we were related through multiple positions that could not be fitted neatly into the box researcher-researched. I tried to ensure that my relationship and every interaction with them was one of empathy and respect. In general terms, I had a smooth relationship with all of them. They were keen to collaborate and mostly saw the experience as way to help my studies and as an opportunity to talk about issues they recognize affect their daily lives but have rarely spoken about. I am conscious that I am the researcher and the one writing about their experiences and lives in a different language than the one they speak and continue to be mindful through reflexivity and adherence to feminist principles.

\section{Mapping Women's Daily Trajectories to Work}

My process of selecting the specific mapping methods was guided by two premises of feminist epistemology. First, it was important that the mapping techniques offered me the possibility to put women's voices of their experiences at the centre. This fits my aim to do anti-oppressive research (Brown \& Strega, 2005), and research that promotes women's 
right to self-representation. It is a standpoint against a western traditional research knowledge which is based on the knowledge that claims disembodiment, neutrality, universality and objectivity. Following feminist theories, my research acknowledges the subjectivity of the experience as a way to bring to academia what women feel and think about their own reality (Kimpson, 2005). I recognize the partiality of knowledge and its multiple perspectives (Haraway, 1988; Harding, 1986; Hiemstra \& Billo, 2017; Moss, 2002). Second, I looked for mapping methods that would allow me to bring together embodiment and space from an intersectional perspective. I wanted to explore how the women feel and live the materiality and subjectivity of public spaces.

I chose the guiding method of trajectory mapping because it allowed me to show how women's trajectories are composed of several moments in time that intersect with specific spaces. It also allowed me to demonstrate the difficulties and constraints they encounter in terms of urban dynamics, urban infrastructure and services in each of those moments. I faced the challenge of paying attention to intersectionality informing those trajectories and the urban experience of women. I found a way forward in the method of "Relief Maps" developed by Dr. María Rodóde-Zárate (2014). Rodó de Zárate has developed a way to analyse the intersectionality of the experience in public spaces and how to portray it graphically. Trajectory methods and relief maps in combination, helped me to map the emotions women experience in those different moments and spaces. In addition, I chose to do accompanied trajectories and walking interviews with the women, which helped me to deepen the understanding of their experiences and context.

I always used the methods in combination. Every time I met one of the women either to have a chat, to accompany her in her trajectory or to have a walking interview, I gathered information that was complementary for the set of methods. Then I systematized the information according to the method.

\section{Subjective Trajectory Mapping}

I started mapping women's daily trajectories to work by talking with them about their daily routines. This process helped me to identify that their trajectories are made of specific moments in which they traverse different urban spaces. I used two specific techniques: (1) The mapping of emotions, which consists of representing in maps the emotions people 
face in different spaces based on their subjective experience, and (2) the use of maps to collect emotional data, which consists of the use of maps to ask for the emotions and memories that people have lived in a place (Griffin \& Mcquoid, 2012: 292-295). Following these two ways of data collection, I gathered the following information:

- general data of the trajectories: e.g. starting point and destination point; time spent by mode and type of trajectory;

- gendered and embodied feelings: emotions and constraints faced in the different moments and spaces they go through in their trajectory (in relation to the gendered dynamics, infrastructure and violence);

- strategies (personal and/or collective) they use (at different moments in time) to overcome the constraints and to transform the urban spaces they navigate in.

The first main challenge I faced was to identify the moments and spaces of the women's trajectories. I first had long conversations with three of the women (M.A., R.O. and M.I.) and systematized the narratives of their journeys in order to identify the most important spaces they go through daily and the differences in terms of time (day and night) and season of the year (rainy season, Christmas season). Another challenge was to decide how to do the mapping. I grappled with the decision of whether to use only questionnaires or to also use Geographical Information System $(\mathrm{GIS})^{4}$ tools. I had thought of giving them a cell phone with an app. After these first meetings, I realized that using GIS tools would represent danger for the women in terms of safety because of the very high rates of robbery in public transportation or in the streets. One of the strategies that the women use is to not use their cell phones in public or even to carry a very cheap one not to put themselves at risk. I decided to gather the information by notes, questionnaires and voice recording and analysed this data using GIS, which allowed me to represent the results in the form of a map (Fig. 9.1).

To deepen the understanding of the information, I used two complementary methods: relief maps and walking interviews.

\footnotetext{
${ }^{4} \mathrm{~A}$ geographic information system (GIS) is a scheme for gathering, managing, analysing and representing geographical data.
} 


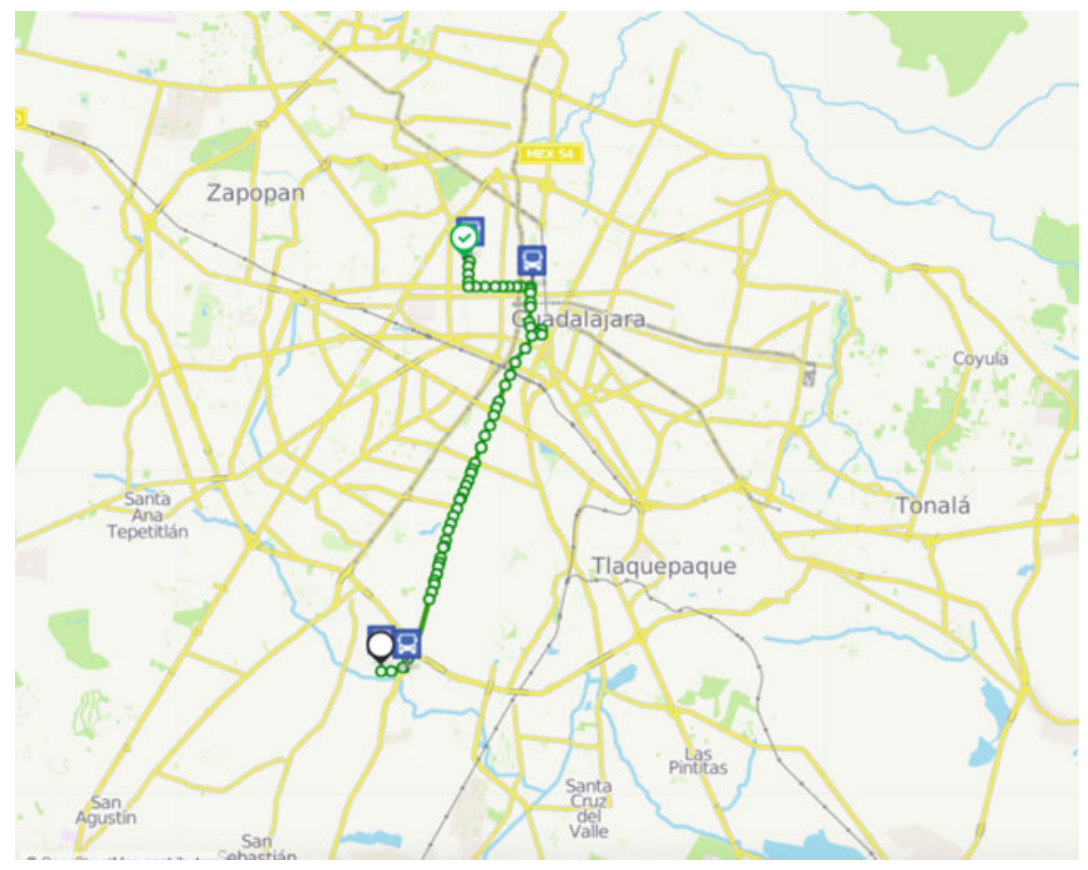

Fig. 9.1 M. A.'s Trajectory map. Author's data. Moovit App (2019)

\section{ReLief Maps}

As explained above, in order to gain insight into the embodied and intersectional experiences of the urban spaces in women's daily trajectories, I used the method of Relief Maps developed by Rodó-de-Zárate (2014). This technique was helpful to think through the lived experience intersectionally and in relation to different spaces, in a way that can be systematized. To collect the data, I used a set of matrixes based on emotions of comfort and discomfort and asked women to describe how they feel in different places according to different intersections (gender, ethnicity/skin colour, class, etc.). The chosen places were decided on by first mapping their trajectories and identifying the different moments of their journeys. Then, the information was represented in a graphic way through the online software also developed by Rodó de Zárate. 
The relief maps were a tool to understand how women's subjectivity was constructed in different spaces as they move across the city and as they revealed how the power relations operate socially and spatially. As Rodó-de-Zárate and Estivill i Castany (2016: 29) commented: "In this sense, the maps allow us to analyse the narratives of the lived experience based on the intersectional discomfort and situated experience, putting emphasis on the daily (im)mobilities and the strategies used". 5

Making the relief maps was logistically quite complicated. The information to make the maps can be gathered and systematized immediately through the online software developed by Rodó de Zárate (2014), but you need an internet connection. Many times, I met the women in places where no internet connection was available or they had very limited time. So, I decided to record the information by printing the questionnaires available in the online software. Similarly, the other difficulty to make them right away was that the conversations evolved, which led me to incorporate more power structures and places, which is why I decided to make the maps at the end.

\section{Accompanied Trajectories and Walking Interviews}

As explained above, in order to deepen the understanding of the data collected by the trajectory emotional mapping and the relief maps, I conducted walking interviews. A walking interview is a spatial experience itself that can provide immediate narratives of a place but also stimulates the recall of memories and feelings. It is an embodied method that brings together active connections among body and spaces. The method helped me to engage more with the women and their experiences while walking and talking together in different places that are important in their daily trajectories (King \& Woordroffe, 2019: 1273-1275). The walking interviews followed a semi-structured interview approach and were useful to explore the most important details that come out of the reliefs and emotional maps.

One of the biggest difficulties to execute the walking interviews was to pay attention to the conversation, the space and our safety at the same time. Women expressed several concerns especially about my safety. They said they were used to taking care of themselves but that they were

${ }^{5}$ Translated from Spanish by author. 
worried about me, especially when I had to go back home, which usually was late at night. Most of them checked via WhatsApp that I arrived home safe. That is one of the strategies women normally use to take care of their daughters, mothers or female friends.

\section{Cartographies, Public and Private Urban Spaces and Normative Bodies}

In this section I briefly examine some of the main findings of the comprehensive cartographies I made of women's trajectories to work by public transportation. I have made a selection of those that shed light on the type of analyses that feminist mapping methods provide in relation to women's urban lives and to the more relevant debates about urban spaces and embodiment. By doing so, I argue that feminist mapping is a strong feminist tool to understand gendered urban identities and thus the mutual constitution of embodiment and space.

In their movement across the metropolis, women go through different places and spaces: the streets of their neighbourhoods, the bus, the metro, the park, etc. In those intersections of encounter and interaction, multiple meanings are inscribed in women's embodiment. Safety is one of the main issues that affects their embodied urban experience. Women's daily trajectories to work are inserted in a context of increasing narco-related violence, high rates of sexual harassment and gender-based violence in public spaces. At the national level, in the last ten years, the number of feminicides committed in public spaces quadrupled (Data Civica, 2020: 27). Here are some examples of the ways women face such safety issues. Women prioritize safety and in order to do so can change their routes even when that means taking more transport units-which is also more expensive-or having longer trajectories. For example, M.I. changed her route because she felt the bus 380 , that would be a faster way to go to work, was making her feel unsafe. Also, women choose their way of dressing according to the trajectory. For example, M.I. knows she will fall asleep in the bus, so she wears blouses that cover her enough as a way of preventing sexual harassment. Women who have daughters prioritize the safety of their daughters, at the expense of exposing themselves. For example, M.A. and M.R. accompanied their daughters to work in the early morning even when that meant waiting in the darkness before their workplaces opened. All this means that women pay for their safety: to take more transport units or private taxis to have safer trajectories. Every 
woman deals with this in a personal way even if it is (invisible to the authorities) a structural gender issue.

Safety issues are interrelated with the emotions women most frequently feel on their journey. The relevance of emotions for the material urban experience is a key element for feminist cartographies because they recognize emotions as a legitimate form of knowledge and fundamental for the understanding of spaces (Pirani et al., 2020). In my cartographies, fear is the most frequent emotion women feel in public spaces. Fear and genderbased violence in public spaces constitute an expression of exclusion. It puts limits to women's access and enjoyment of public spaces.

In relation to the public-private dichotomy, women's mobility is inherent to both the individual and private and to the social and public dimension of the body (Butler, 2004; Petchesky, 2015). Through analysing women's daily trajectories to work, I saw how the public and private transcend and intersect with each other. The cartographies show that the dichotomy is not only inherent to the public spaces or the public dimension of their embodiment, but it also inscribes meaning to their private spaces and to the private dimension of their own bodies. In public spaces, women's bodies become much more public than in any other place. There they are subject to public scrutiny under the social and cultural normative (of age, class, gender, ethnicity, skin colour and ableness) power structures, which plays a major role in shaping their urban experience. The cartographies show that when a female body doesn't comply with what is considered the norm, her embodied urban experience is marked by oppressing forces.

From my research gender is the most problematic power structure and axis of identity for all women in all the places. When other power structures of identity are relevant for a woman, they intersect with gender. For example, the most relevant axis of identity for M.A. are gender, social class and corporality (see Fig. 9.2). She feels her social class status is related to her situation as a single mother. At her home, the only axis that causes her discomfort is gender. She says this is because of her role as a woman and as a single mother. The public places where she experiences relief because of her gender identity are upper class and middle-class neighbourhoods. In those places, she feels less threatened because of her gender. But at the same time, in those places she feels discriminated due to her social class. A lower-class neighbourhood is where the three most relevant axes of M.A.'s identity combine to bring discomfort. M.A. feels threatened because of gender, corporality and social class. In her body these three 


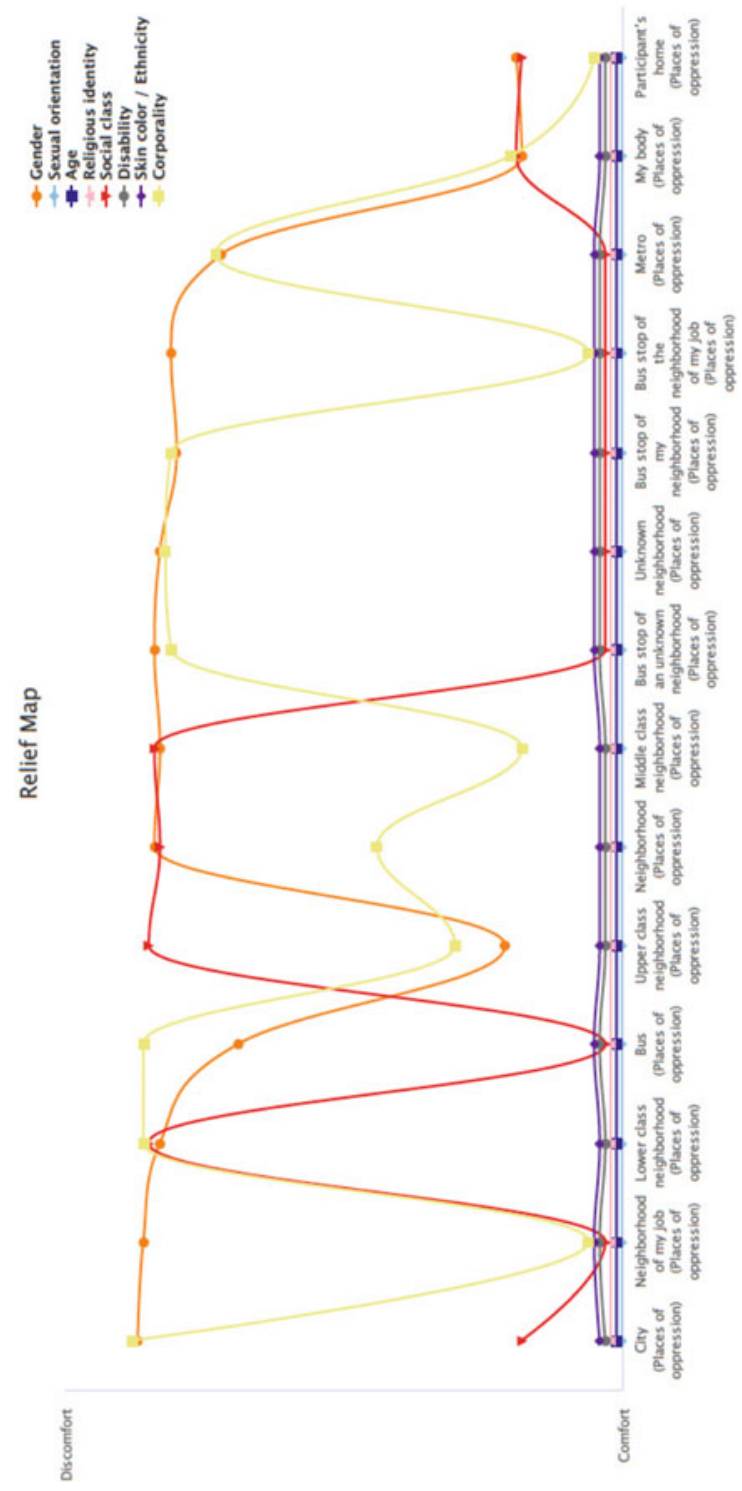

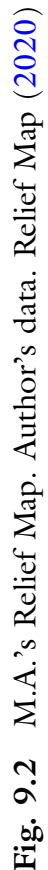


axes intersect. She explained that it is related to the frustration of not being able to earn more money, not having enough time to exercise to have a healthier body and because of the pressure of being a woman and her role as a single mother.

Skin colour is a highly relevant power structure that negatively affects women with racialized brown skin colour. They experience negative emotions regarding the way they are seen and treated in many public spaces. In M.O.'s experience "I got used to live with it, but obviously, I have felt I'm looked down, what else for? For being black and talking about colour, I am not even black..." (M.O., 2020).

The gendered stereotypes and normative aspects of corporality are another power structure that deeply affects women's urban experience. Women's corporality, whether defined as skinny or fat, plays a major role in how they feel and experience different public urban spaces. The logic that operates behind this is the sexualization of the female body and the gendered stereotypes in which women are supposed to be skinny in order for their bodies to be "desirable" for the men's gaze. So, women who are considered skinny are harassed due to this "desirability". Women who are considered fat are often insulted and harassed with negative comments about their bodies.

Age is another power structure that affects women in the city, predominantly in two ways. Young women (18-25) are more often sexually harassed in public spaces than older women (Rozas \& Salazar Arredondo, 2015: 7). Also, they are the ones most likely to use public transit as their main form of transportation. The average age of women who use public transportation is 35 years old, when women have more income needs and people (mostly children) depend on them (Godinez et al., 2020: 54). On the other hand, old women have a hard time dealing with the urban infrastructure. The time given by traffic lights to cross a street does not allow for their slow pace. The buses usually travel at such a high speed which demands plenty of strength to hold yourself steady or to climb the stairs. Only $9.7 \%$ of the female users of the public transportation system are 65 years old or older (Godinez et al., 2020: 54).

The able body is a power structure that makes it very difficult for women to navigate the city. The city's logic, rhythms and infrastructure are designed for the able-bodied. This affects the urban experiences of old women and women living with physical and mental disabilities. There are not enough ramps, accessible signage is deficient and in general the urban infrastructure is not inclusive of different physical needs. 
In addition, their sexual orientation or non-normative gender expression puts queer people at risk of being attacked. Between 2007 and 2019, 100 hate crimes were committed in Jalisco state. All of them are against LGBTTIQ ${ }^{6}$ people because of their sexual orientation and/or gender expression (Zona Docs, 2020). In Z.I.'s experience: "I have felt the social rejection when walking in the streets hanging out with another woman. It makes me frustrated, because I felt nervous of kissing a girl in the street. I feel we may be hit"7 (Z.I., 2020).

Finally, religion is a power structure which might be subtler to note in the urban dynamics, but in a profoundly catholic country, not being religious or professing a different religion puts many women in uncomfortable situations.

Women negotiate and re-signify in their embodiments and place experiences of oppression and exclusion. But also, I found that some meanings inscribed in the home which are re-signified and negotiated in the public space. This is another example of the way in which the public and the private transcend each other and opens up the question of whether traditional connotations of private-public are breaking down. I found that women were still very constrained by the dichotomy of private/public and feel they are subjects of violence when they trespass the boundaries.

\section{CONCLUSION}

Mapping women's daily trajectories from an intersectional and embodied perspective sheds light on the ways in which power structures shape women's urban experiences. It leads to a deeper understanding of the mutual constitution of embodiment and space and how such interplay is mediated by the intersection of certain power structures. In my research, I problematized the power structures and identity axes of gender, age, social class, skin colour, corporality, religion, sexual orientation and disability through the methods of emotional mapping, relief maps and walking interviews. These methods helped me to analyse the ways in which specific power structures (which are always geographically and historically contingent) shape women's urban lives.

\footnotetext{
${ }^{6}$ Lesbian, gay, bisexual, transgender, transsexual and queer.

${ }^{7}$ Translated by author.
} 
Feminist cartographies provide mapping methods which bring together the materiality and subjectivity of women's urban experience from an intersectional perspective. The methods put women's experiences at the centre and bring in their own voices and subjectivities about how they live in the urban environment to academia. Mapping becomes a tool to claim women's right to create and recreate urban geographies. Regarding the specific mapping methods used, it is important to choose the appropriate tools according to specific objectives. What I have called comprehensive women's embodied urban cartographies are a combination of mapping methods that respond to my research objectives and feminist epistemologies. However, I hope they can be useful for other feminist researchers to think, reflect and research about gender and spaces in a way that addresses the symbolic and material lived experience of today's urban spaces.

\section{REFERENCES}

Aceves, J., Torre, R., \& Safa, P. (2004). Fragmentos Urbanos de una Misma Ciudad: Guadalajara ("Urban fragments of the same city: Guadalajara"). Espiral, XI, 320.

Bondi, L. (1998). Gender, class, and urban space: Public and private space in contemporary urban landscapes. Urban Geography, 19(2), 160-185.

Bondi, L., \& Rose, D. (2003). Constructing gender, constructing the urban: A review of Anglo-American feminist urban geography. Gender, Place and Culture, 10, 229-245.

Brown, L., \& Strega, S. (2005). Research as resistance. Critical, indigenous and anti-oppressive approaches. Canadian Scholars Press.

Butler, J. (2004). Precarious life: The powers of mourning and violence. Verso.

Calonge Reillo, F. (2014). El Capitalismo de Acumulación Flexible y las Movilidades Laborales y Espaciales de las Mujeres en el Área Metropolitana de Guadalajara ("Capitalism of flexible accumulation, labour and spatial mobilities of women in the Metropolitan Area of Guadalajara"). La Ventana. Revista De Estudios De Género, 5(40), 88-133.

Cuadra Urbanismo. (2016). Análisis Del Mercado Inmobiliario En La ZMG ("Analysis of the real state market in the Metropolitan Area of Guadalajara"). Guadalajara, Jalisco: Cuadra Urbanismo. Retrieved October 22, 2017, from http://mexico.itdp.org/wp-content/uploads/Análisis-de-mercado-inm obiliario-en-la-ZMG.pdf.

Data Civica. (2020). Claves para Entender y Prevenir los Asesinatos de Mujeres en México ("Keys for understanding and preventing assasanations of women in Mexico"). Data Civica. 
De La Torre, R. (1998). Guadalajara Vista Desde la Calzada: Fronteras Culturales e Imaginarios Urbanos ("Guadalajara Seen from La Calzada: Sociocultural Borders and Urban Imaginaries"). Alteridades, 8, 55.

D'Ignazio, C., \& Klein, L. F. (2020). Data feminism. MIT Press.

El Informador. (2014). Ocho de Cada Diez Mujeres Sufren Acoso en el Transporte Público ("Eight out of ten women suffer harassment in the public transport"). Retrieved March 2017, from http://www.informador.com.mx/ jalisco/2014/550393/6/ocho-de-cada-10-mujeres-sufren-acoso-en-el-transp orte-publico.htm.

Griffin, A. L., \& McQuoid, J. (2012). At the intersection of maps and emotion: The challenge of spatially representing experience. Kartographische Nachrichten, 62(6), 291-299.

Godinez, J., De la Cruz Castillo, E., Martínez Díaz, S., Guerra Hernández, M., Granada, I., \& Glen, C. (2020). Patrones de Movilidad e las Mujeres en el Corredor Intermodal del Área Metropolitana de Guadalajara ("Mobility paterns of women in the intermodal passageway of Guadalajara Metropolitan Area"). BID.

Haraway, D. (1988). Situated knowledges: The question in feminism and the privilege of partial perspective. Feminist Studies, 14(3), 575-599.

Harding, S. (1986). The science question in feminism. Cornell University Press.

Hiemstra, N., \& Billo, E. (2017). Introduction to focus section: Feminist research and knowledge production in geography. The Professional Geographer, 69(2), 284-290.

IIEG (Instituto de Información Estadística y Geografía). (2010). Indice De Marginación Por Colonia ("Marginalization index by neighborhood"). IIEG. Retrieved September 2, 2018, from https://iieg.gob.mx/general.php?id=4\& idg $=72$.

IIEG (Instituto de Información Estadística y Geografía). (2017). Alcanza Área Metropolitana de Guadalajara los 5 Millones de Habitantes ("Guadalajara's Metropolitan Area reaches 5 million of inhabitants"). Instituto de Información Estadística y Geogragía (Institute of Statistical Information and Geography). Retrieved June 21, 2018, from http://iieg.gob.mx/strategos/alcanza-areametropolitana-de-guadalajara-los-5-millones-de-habitantes/.

Jalisco Cómo Vamos. (2018). Ser Mujer En Guadalajara ("To be a woman in Guadalajara"). Jalisco Cómo Vamos. Retrieved October 10, 2018, from http://www.jaliscocomovamos.org/ser-mujer-gdl.

Kimpson, S. (2005). Stepping off the Road: A Narrative (of) Inquiry. In L.A. Brown \& S. Strega (Eds.), Research as resistance: Critical, indigenous and anti-oppressive approaches. Toronto, ON: Canadian Scholars' Press, 73-96.

King, A. C., \& Woodroffe, J. (2019). Walking interviews. In P. Liamputtong (Ed.), Handbook of research methods in health social sciences (pp. 1269-1290). Springer. 
Lidón, A. (2013). Corporalidades, Emociones y Espacialidades: Hacia un Renovado Betweenness ("Corporealities, emotions and spatialities: Torwards a renewed betweenness"). RBSE Revista Brasileira De Sociologia Da Emoção, $11(33), 698-723$.

Limberopulos Fernández, Y., \& Cervantes García Rulfo, L. (2017). Coordenadas de la Marginación en Guadalajara ("Coordinates of the marginalization in Guadalajara") Horizontal. Retrieved October 10, 2018, from https://horizo ntal.mx/coordenadas-de-la-marginacion-en-guadalajara.

M.O. (2020, February 2). Personal Communication (Personal interview).

Moss, P. (2002). Taking on, thinking about, and doing feminist research in geography. In P. Moss (Ed.), Feminist geography in practice: Research and methods (pp. 1-20). Blackwell Publishers.

Moovit App. (2019). Moovit App. Public transport application. Retrieved November 2019, from https://moovitapp.com/guadalajara-2900/poi/en.

Petchesky, R. (2015). Owning and disowning the body: A reflection. In R. Baksh-Soodeen \& W. Harcourt (Eds.), The Oxford handbook of transnational feminist movements (pp. 252-270). Oxford University Press.

Pirani, N., Ricker, B. A., \& Kraak, M. J. (2020). Feminist cartography and the United Nations sustainable development goal on gender equality: Emotional responses to three thematic maps. The Canadian Geographer, 64(2), 184198.

Ramírez Sáiz, J., \& Safa Barraza, P. (2009). Tendencias y Retos Recientes en Tres Metrópolis Mexicanas: Ciudad de México, Guadalajara y Monterrey ("Tendencies and recent challenges in three Mexican Metropolis: Mexico City, Guadalajara and Monterrey”). Cuadernos De Antropología Social, 30, 77-92.

Relief Maps. (2020). Relief maps. Online Software. Retrieved May 2020, from https://reliefmaps.cat/en/.

Rodó-de-Zárate, M. (2014). Developing geographies of intersectionality with relief maps: Reflections from youth research in Manresa, Catalonia. Gender, Place and Culture-A Journal of Feminist Geography, 21(8), 925-944.

Rodó-de-Zárate, M., \& Baylina, M. (2018). 'Intersectionality in Feminist Geographies.' Gender, Place \& Culture, 25(4), 547-553.

Rodó-de-Zárate, M., \& Estivill i Castany, J. (2016). ¿La Calle es Mía? Poder, Miedo y Estrategias de Empoderamiento de Mujeres Jóvenes en un Espacio Público Hostil ("Is the street mine? Power, fear and empowerment strategies of young women in a hostile public space"). Emakunde.

Rozas, P., \& Salazar Arredondo, L. (2015). Violencia de Género en el Transporte Público: una Regulación Pendiente. Naciones Unidas, CEPAL.

UN-Habitat (United Nations Human Settlements Programme). (2012). The state of Latin American and Caribbean cities 2012: Towards a new urban transition. UN Habitat. 
Zona Docs. (2020). Recudrece la Violencia en Contra de la Población LGBTI Durante la Contingencia Sanitaria en Jalisco ("Violence against LGBT people rages during the health congintency in Jalisco"). Retrieved February 20, 2021, from https://www.zonadocs.mx/2020/04/25/recrudece-violen cia-en-contra-de-poblacion-lgbt-durante-contingencia-sanitaria-en-jalisco/.

Z.I. (2020, February 4). Personal Communication (Personal interview).

Open Access This chapter is distributed under the terms of the Creative Commons Attribution 4.0 International License (http://creativecommons.org/ licenses/by/4.0/), which permits use, duplication, adaptation, distribution and reproduction in any medium or format, as long as you give appropriate credit to the original author(s) and the source, a link is provided to the Creative Commons license and any changes made are indicated.

The images or other third party material in this chapter are included in the work's Creative Commons license, unless indicated otherwise in the credit line; if such material is not included in the work's Creative Commons license and the respective action is not permitted by statutory regulation, users will need to obtain permission from the license holder to duplicate, adapt or reproduce the material.

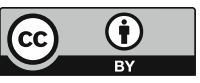

